\title{
Chilaiditi's syndrome as a cause for shock
}

\author{
Sophie Tallulah Boddy, Declan McDonnell, Damian Mayo, Paul Nichols
}

Department of Surgery,

Southampton General Hospital,

Southampton, UK

Correspondence to

Declan McDonnell,

declan@doctors.org.uk

Accepted 20 December 2014

CrossMark

To cite: Boddy ST,

McDonnell D, Mayo D, et al. BMJ Case Rep Published

online: [please include Day

Month Year] doi:10.1136/

bcr-2014-207743

\section{DESCRIPTION}

An 83-year-old man presented to the emergency department (ED) with tachycardia, hypotension and in respiratory distress. Eleven days prior to this he had undergone elective cardiac bypass surgery for angina. A chest radiograph was taken while in ED (figure 1), and shows a good example of Chilaiditi's sign, where bowel becomes interposed between the liver and diaphragm. He was referred to the general surgeons who performed an emergency laparotomy with resection of colon and formation of a colostomy. This was carried out as it was believed the dilated bowel, which was at the level of the heart, compromised venous return to the atria and exacerbated his symptoms. The laparotomy found no bowel ischaemia, but it was distended to the point of serosal tears.

His cardiovascular compromise resolved following the emergency operation and he was transferred to the general intensive care unit and eventually the surgical high-dependency unit. However, after

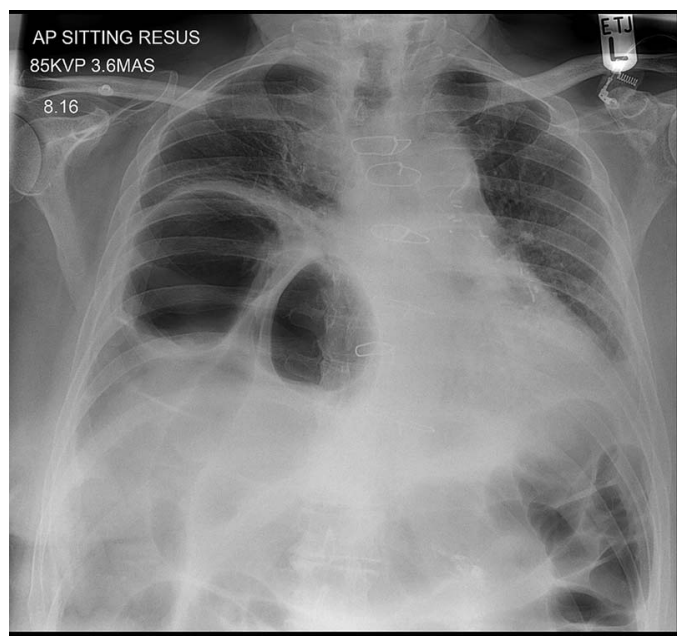

Figure 1 A chest radiograph showing Chilaiditi's sign. several days his condition started to deteriorate and he developed respiratory failure refractory to conventional treatments. Further radiography showed a raised hemidiaphragm with a compressed right lung field. The reduction in lung volume coupled with the development of a hospital-acquired pneumonia led to the decision to return to theatre for plication of the right hemidiaphragm. Following this procedure, and a course of antibiotics, he began to improve clinically.

It was suspected that the raised hemidiaphragm was due to phrenic nerve injury, which complicates approximately $1 \%$ of coronary artery bypass graft procedures. ${ }^{1}$

\section{Learning points}

- Chilaiditi's sign is observed on a chest radiograph when a loop of bowel becomes trapped between the diaphragm and the liver.

- It is normally a benign finding. However, in this patient, the interposition and subsequent distention of the bowel compressed his right atrium and led to obstructive shock.

- An initial misdiagnosis of diaphragmatic hernia was performed on the chest radiograph. CT would therefore be essential in all cases to confirm or refute the diagnosis.

Contributors STB, DMD, DM and PN all coauthored the manuscript. The entire process was overseen by PN.

Competing interests None.

Patient consent Obtained.

\section{REFERENCE}

1 Mehta $Y$, Vats $M$, Singh $A$, et al. Incidence and management of diaphragmatic palsy in patients after cardiac surgery. Indian J Crit Care Med 2008:12:91-5.

Copyright 2015 BMJ Publishing Group. All rights reserved. For permission to reuse any of this content visit http://group.bmj.com/group/rights-licensing/permissions.

BMJ Case Report Fellows may re-use this article for personal use and teaching without any further permission.

Become a Fellow of BMJ Case Reports today and you can:

- Submit as many cases as you like

- Enjoy fast sympathetic peer review and rapid publication of accepted articles

- Access all the published articles

- Re-use any of the published material for personal use and teaching without further permission

For information on Institutional Fellowships contact consortiasales@bmjgroup.com

Visit casereports.bmj.com for more articles like this and to become a Fellow 